\title{
Income Mobility in Old Age in Britain and Germany
}

\author{
Asghar Zaidi \\ Joachim R. Frick \\ Felix Büchel
}

\section{Contents}

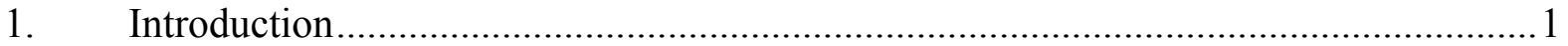

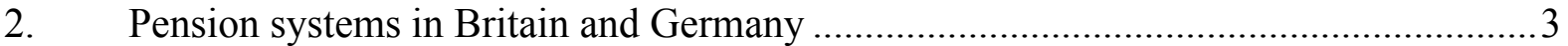

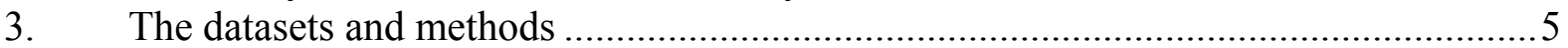

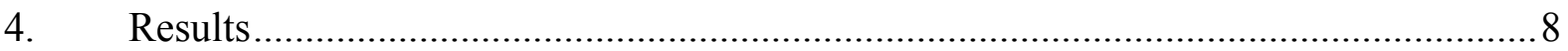

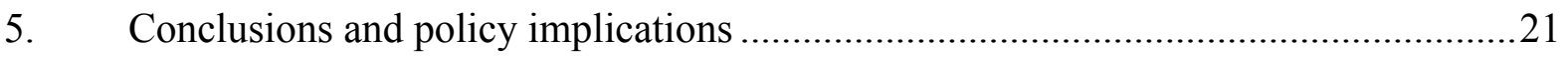

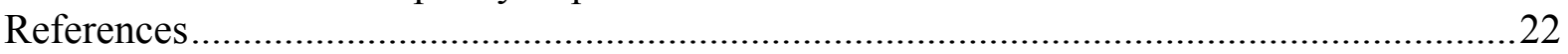

CASEpaper 89

December 2004
Centre for Analysis of Social Exclusion

London School of Economics

Houghton Street

London WC2A 2AE

CASE enquiries - tel: 02079556679 


\section{Centre for Analysis of Social Exclusion}

The ESRC Research Centre for Analysis of Social Exclusion (CASE) was established in October 1997 with funding from the Economic and Social Research Council. It is located within the Suntory and Toyota International Centres for Economics and Related Disciplines (STICERD) at the London School of Economics and Political Science, and benefits from support from STICERD. It is directed by Howard Glennerster, John Hills, Kathleen Kiernan, Julian Le Grand, Anne Power and Carol Propper.

Our Discussion Paper series is available free of charge. We also produce summaries of our research in CASEbriefs, and reports from various conferences and activities in CASEreports. To subscribe to the CASEpaper series, or for further information on the work of the Centre and our seminar series, please contact the Centre Administrator, Jane Dickson, on:

$\begin{array}{ll}\text { Telephone: } & \text { UK+207955 6679 } \\ \text { Fax: } & \text { UK+2079556951 } \\ \text { Email: } & \text { j.dickson@1se.ac.uk } \\ \text { Web site: } & \text { http://sticerd.lse.ac.uk/case }\end{array}$

(C) Asghar Zaidi

Joachim R. Frick

Felix Büchel

All rights reserved. Short sections of text, not to exceed two paragraphs, may be quoted without explicit permission provided that full credit, including (C) notice, is given to the source. 


\section{Editorial Note and Acknowledgements}

Asghar Zaidi is a Research Associate of CASE; he is also a Research Affiliate at the German Institute of Economic Research (DIW Berlin). Joachim R. Frick is a Senior Research Associate at the DIW Berlin. Sadly, Felix Büchel passed away during the completion of this paper; he has been a Senior Research Scientist at the Max Planck Institute for Human Development, Berlin and also a professor at the Department of Economics, Technical University of Berlin.

The authors are grateful to comments by Gert Wagner, Abigail McKnight and by participants at the 2003 Joint EPUNET-BHPS Research conference. The research benefited from earlier work carried out jointly with Katherine Rake and Jane Falkingham and from ongoing work with Klaas de Vos and Björn Gustaffson. The sole responsibility of any errors and interpretations rests with the authors.

The data from the British Household Panel Survey (BHPS) used in this paper were made available through the Data Archive. The data were originally collected by the ESRC Research Centre on Micro-Social Change at the University of Essex. The data for Germany used are drawn from the German Socio-Economic Panel (SOEP) and were provided by DIW Berlin. Neither the original collectors of the data nor the Data Archive, in the case of the British data, bear any responsibility for the analyses or interpretations presented here. 


\begin{abstract}
The increases in human longevity in recent decades and the trends for early retirement have posed new challenges for policy makers, and require a holistic understanding of the processes that influence the economic resources of older people. This paper contributes to this knowledge by examining the income mobility experienced by older people living in Britain and Germany during the 1990s, and by identifying personal attributes and life-course events that influenced its direction and likelihood. The analysis uses the British Household Panel Survey (BHPS) and the German Socio-Economic Panel (SOEP) panel data. The comparative perspective yields insights about the different income experience of older people in the two markedly different welfare regimes. Results show that old-age income mobility is more pronounced in Britain than in Germany, and that in both countries its occurrence is particularly associated with changes in living arrangements, in the employment status of the coresident family members and with widowhood among women. Unemployment during working life is also associated with significant negative later life income mobility. Among those on low incomes, a high share of income from an earnings-related pension had a significant and positive effect in both countries. One policy implication is the need to strengthen the social safety net, to safeguard against downward income mobility in old age, particularly among widows. Policy incentives are required to encourage flexible living arrangements in old age, as well as a greater protection from unemployment during working life, more so in Germany than in Britain.
\end{abstract}

Keywords: Income mobility, old age, pensions, Britain and Germany

JEL number: D31, D63, H55, I31, J14 


\section{Introduction}

This paper reports an investigation of the income experience of older people during the 1990s in Great Britain and West Germany. It examines the extent of the income mobility experienced by older people in the two countries, and identifies the attributes and life-course transitions that influence its direction and magnitude. Britain and Germany were chosen partly because of the differences and similarities in their pensions and old-age income support systems, in particular their different types of public pensions. The economic and social integration of European Union countries, the possible harmonisation of the pension systems, and the need to reform national tax and benefit systems to prepare for an ageing population are the policy contexts of this research.

The paper discusses whether income mobility in old age is to be viewed as a 'good' or a 'bad' thing. Following Atkinson, Bourguignon and Morrisson (1992), the broader social and normative dimensions of income mobility are considered. For society as a whole, income mobility in old age may be considered a positive outcome, in that it implies less 'permanent inequality' and hence allays concerns about rising cross-sectional inequality among older people. From an individual's point of view, whether income mobility is experienced as 'good' or 'bad' is likely to be mediated by several factors, including whether the income change was anticipated or not, and how successfully the person copes with the change. The older population has specific characteristics that lend a unique, often negative, dimension to their experience of income fluctuations. For instance, they may not be able to change their employment status (meaning, in most cases, take paid employment), or borrow and lend in the capital market as freely as younger people, and therefore are more likely to experience welfare losses from income changes than younger people. For these reasons, income mobility in old age is arguably synonymous with income insecurity. Consequently all forms of income fluctuations (downward or upward) can be linked with welfare losses among individual older people.

There are large gaps in the research literature on these issues. For instance, most studies of the individual welfare of older people are based on annual crosssection data which provides no more than a snapshot analyses (e.g. Torrey and Smeeding 1992; Hagenaars, De Vos and Zaidi 1994; Tsakloglou 1996; Disney and Whitehouse 2001, Smeeding 2001). ${ }^{1}$ Although these analyses provide

1 Important exceptions are recent studies by Burkhauser, Lillard and Valenti (2001); Zaidi, Rake and Falkingham (2001); Zaidi and De Vos (2002) and Zaidi, Frick and Büchel (2003). 
insights into the income situation of older people as compared to the overall population, they provide little information about income dynamics during old age, which our research has sought to do. The studies that have reported income dynamics in old age and its correlates have restricted themselves to single events of interest, notably the most important lifecourse transitions such as widowhood ( $c f$. Burkhauser, Lillard and Valenti 2001), or do no more than compare two points in time. For example, Disney et al. (1997) analysed income dynamics for British pensioners using the two-wave data from the Great Britain Retirement Surveys of 1988/89 and 1994.

These information gaps were the motivation to address the following research questions: how does the income experience of older people vary in countries with different institutional arrangements for income provision in old age? What factors and life-course transitions trigger income mobility in old age, and how do these vary by country? Are the influential factors distinctive among those with low incomes? This last question has special social policy relevance since the experience of those on low incomes provides insights into important 'social protection' or social security questions (although we are not specifically concerned with defining a discrete poverty line). Income losses, or downward income mobility, among those already on low incomes clearly present a high risk of severe poverty.

It is emphasised that the analysis reported in this paper emphasises income mobility per se rather than poverty dynamics, as is more usual, e.g. Holden et al. (1986, 1988) and Hurd and Wise (1989). The focus is consistent with our view that income fluctuation ipso facto affects an older person's welfare irrespective of whether it alters her or his poverty status. Individuals who experience changes in income may be unaware of the poverty threshold, and are therefore unaware whether that change has taken them into poverty. Moreover, while poverty dynamics is an important research domain in its own right, findings and their interpretation are strongly influenced by the conceptualisation and measurement of 'poverty'.

The remainder of this paper is organised as follows. Section 2 sets out the institutional context by providing information about the pension systems operating in Britain and Germany. Section 3 describes the salient features of the two datasets as well as the methodology adopted in producing the empirical results. Section 4 analyses the descriptive and multivariate results. Section 5 gives a synthesizing discussion and highlights the policy implications of our findings. 


\section{Pension systems in Britain and Germany ${ }^{2}$}

\section{The basic state pension}

An important component of the British pension system is the mandatory basic state pension: it is close to being universal, a flat-rate payment and during the 1990s was indexed in line with inflation (in prices not wages). Since the basic state pension is lower than the minimum subsistence level, to maintain a minimum standard of living many British pensioners rely on other private resources or means-tested income support, including the 'Minimum Income Guarantee'. Entitlements to the basic state pension are accumulated mainly by contributions when in paid employment, but contributions made by a spouse are also instrumental. A system of National Insurance credits ensures that the vast majority in practice qualify for the basic state pension, even those who have not been in the labour market.3 In Germany, there is no comparable basic state pension. Those not entitled to receive sufficient public pensions are referred to the welfare system for the minimum social assistance which is means-tested. It has been evaluated as a successful instrument in 'shielding older people from poverty' (Börsch-Supan 2001: 22).

\section{Earnings-related pensions}

The state-managed earnings-related second pension in Britain has been losing its value over time, and an increasing percentage of earnings-linked pension income derives from employer managed pension schemes in the private and public-sectors (e.g. teachers, NHS, civil servants, local authorities). In contrast, in Germany almost all earnings-related pensions are managed by the public pension system; indeed, approximately 85 per cent of all pension income in Germany is from public sector schemes (Börsch-Supan 2001: 15).

In Germany, the participation in earnings-related pensions has been mandatory, thus a large proportion of older people draws income from these schemes. In Britain, all employees whose earnings are between the Lower Earnings Limit (LEL) and the Upper Earnings Threshold (UET) have a mandatory form of

2 The information on the British pension system is drawn from Emmerson and Johnson (2001), Blundell and Johnson (1999), Dilnot et al. (1994) and Emmerson (2003). The corresponding information about Germany is obtained from Börsch-Supan and Schnabel (1999) and Schmähl (1998, 2003).

3 Note here that the Home Responsibilities Protection (HRP) Act 1978 in Britain, which reduced the number of years of contributions for women by the number of years equal to those spent out of the labour force looking after children, came too late for those women who were aged 60 or more years in the base year of the analysis (1990/91): these women were born in 1930 or before and would have already passed the childbearing ages. 
earnings-related pensions, although there is a choice between state-managed schemes or 'contracting out' to suitable alternative schemes. In both countries, these schemes provide a good replacement of earnings (to a maximum of $70 \%$ ) for those who contributed for most of their working life. By international standards, the German public pension scheme has an unusually high earningsreplacement rate, and also has generous incentives for early retirement and good coverage for survivors, viz. widows and widowers (Schmähl 2003; BörschSupan 2001). In Germany, if there are periods during which an individual pays no pensions contributions to a scheme, e.g. time spent in higher education, child-care, military service, illness and unemployment, replacement contributions can be credited. In Britain, however, private occupational pensions make only limited provisions for such absences from the formal labour market. Until 1992, public pensions in Germany had been indexed to average gross wages, but a reform in that year changed the index to net wages. British private occupational pensions are indexed differently, the large majority to price inflation only (Government Actuary's Department 2003).

Another difference is that in Germany most public pensions are defined-benefit schemes, whereas in Britain private occupational pension schemes take many forms including defined-contributions. ${ }^{4}$ The latter, although more flexible and portable, have two problems: the employers' contributions are generally lower and it is the employee who bears the investment risk. As a result, the German public pension scheme not only performs better in replacing earnings but also is more secure than British private occupational pensions. Since the German public pension is indexed in line with wages (with very little difference across occupational sectors), it is also more likely to hold its real value than the British occupational pensions whose indexation differs across sectors and at its best it rises in line with the retail price index only. ${ }^{5}$

\section{Private personal pensions}

In Britain, an increasing number of people are opting for private personal pensions, and they are now a prevalent form of pensions amongst those in the younger working ages. In Germany in 2002, the federal government followed most other industrialised nations by initiating private retirement schemes to

4 The defined-benefit type schemes offer pension income that is based on a percentage of the member's final or lifetime salary. The defined-contribution schemes, on the other hand, offer an arrangement in which the pension income is drawn from an annuitisation of the accumulated principal based on contributions made by the member and the employer, together with any interest and investment returns.

5 The UK Government Actuary's Department (2003: 53) estimates that the majority of large occupational pension schemes in Britain awarded pension increases in the period 1996 to 2000 that were broadly in line with the Retail Price Index only. 
complement the pay-as-you-go system, and many firms now support additional private personal schemes (Betriebsrenten) for their employees. Almost every other German employee is a member of such schemes. In this study's sample of German older people during the 1990s, however, only a few had private personal pensions.

\section{The datasets and methods}

The British data were drawn from the first nine waves of the British Household Panel Survey (BHPS) conducted in 1990/91 to 1998/99; and the German data are from 11 waves of the German Socio-Economic Panel (SOEP) covering 1990 to 2000. Because of the specific situation in East Germany and the unavailability of annual income data for the first two years of the transition from state communism, 1989-90, the analyses have been restricted to West Germany. Both surveys provided longitudinal information on the annual income and other attributes of private households. In SOEP, annual income is estimated by combining the average monthly income from any source at individual and household level with the number of months in which different sources of income were received during the year. In BHPS, annual income is estimated by an extrapolation from current monthly income. ${ }^{6}$ Salient features of the two surveys are summarised in Table 1.

Since individuals share resources with other members of their households, the economic resources of older people will not be adequately described by individual (or benefit-unit) income alone, and for this reason household income has been analysed. For similar reasons, net household income ('post-tax posttransfer income') was preferred to gross income. All the empirical results have been expressed in real terms. ${ }^{7}$ Throughout the paper, old age is defined by a minimum age of 60 years and by a further restriction that the person was no longer in employment. To allow for reduced per capita living costs with increasing household size, equivalised income is used. The equivalence scale is approximated by the square root of the household size, as commonly used in cross-national comparisons (e.g. Förster and Pellizzari 2000). By examining equivalised income rather than total household income, we automatically

6 We refer to Burkhauser et al. (2001) and Böheim and Jenkins (2000) for a more elaborate discussion on the derivation of annual income in SOEP and BHPS, respectively.

7 The correction for price inflation has been made using the Consumer Price Index (CPI) in Germany and the Retail Prices Index (RPI) in Britain. A more appropriate index may have been a Pensioners' Price Index, but a comparable index was not available for the two countries. 
correct for changes in family composition (albeit imprecisely) from one year to the next.

\section{Table 1: Main characteristics of the British Household Panel Survey and the German Socio-Economic Panel Survey}

\begin{tabular}{|c|c|c|}
\hline Attribute & British Household Panel Survey & German Socio-Economic Panel \\
\hline $\begin{array}{l}\text { Type and } \\
\text { frequency }\end{array}$ & $\begin{array}{l}\text { Longitudinal survey of } \\
\text { households; interviews with those } \\
\text { aged } 16 \text { or more years on } 1 \mathrm{st} \\
\text { December of the survey year. }\end{array}$ & $\begin{array}{l}\text { Longitudinal survey of households; } \\
\text { interviews with those who are aged } 17 \\
\text { or more in each survey year. }\end{array}$ \\
\hline $\begin{array}{l}\text { Population } \\
\text { coverage }\end{array}$ & $\begin{array}{l}\text { Representative of all private } \\
\text { households in Great Britain in } \\
\text { 1991. In subsequent years, the } \\
\text { original sample members (and } \\
\text { newly eligible household } \\
\text { members) were re-interviewed. }\end{array}$ & $\begin{array}{l}\text { Representative of all private } \\
\text { households in West Germany in } 1984 \\
\text { (ex-East Germany since 1990). In } \\
\text { subsequent years the original sample } \\
\text { members (and newly eligible } \\
\text { household members) were re- } \\
\text { interviewed. Additional random } \\
\text { samples in 1995, } 1998 \text { and } 2000 \text { (to } \\
\text { cover new immigrants). }\end{array}$ \\
\hline $\begin{array}{l}\text { Sample } \\
\text { size }\end{array}$ & $\begin{array}{l}5,000 \text { households, } 10,000 \\
\text { individuals }\end{array}$ & $\begin{array}{l}\text { 1984: } 6,000 \text { households }(12,000 \\
\text { individuals). } 2001: 12,000 \text { households } \\
\text { ( } 22,300 \text { individuals) }\end{array}$ \\
\hline $\begin{array}{l}\text { Response } \\
\text { rate }\end{array}$ & $\begin{array}{l}\text { Response rate exceeded } 70 \% \text { in } \\
\text { first wave data; most of the } \\
\text { observed attrition during the first } \\
\text { two waves. }\end{array}$ & $\begin{array}{l}\text { Initial response rate varied by sub- } \\
\text { sample between c. } 50 \text { and } 70 \% \text {. Wave- } \\
\text { to-wave response rates exceed } 95 \% \text {. }\end{array}$ \\
\hline $\begin{array}{l}\text { Income } \\
\text { variable }\end{array}$ & $\begin{array}{l}\text { Annual income derived from } \\
\text { current (monthly) income from } \\
\text { different specified sources, and } \\
\text { the number of months from } 1 \\
\text { September of the previous year to } \\
31 \text { August of the survey year that } \\
\text { each source contributed income. }\end{array}$ & $\begin{array}{l}\text { Annual income derived from current } \\
\text { (monthly) income from different } \\
\text { specified sources, and the number of } \\
\text { months during the previous calendar } \\
\text { year that each source contributed } \\
\text { income. }\end{array}$ \\
\hline $\begin{array}{l}\text { Income of } \\
\text { new } \\
\text { entrants } \\
\text { and leavers }\end{array}$ & $\begin{array}{l}\text { Income recorded of only those } \\
\text { present at the time of the survey. }\end{array}$ & $\begin{array}{l}\text { Income recorded of all present at the } \\
\text { time of the survey (except for non- } \\
\text { responding individuals). }\end{array}$ \\
\hline $\begin{array}{l}\text { Years used } \\
\text { in the study }\end{array}$ & $\begin{array}{l}1991 \text { to } 1999 \text {; income for } \\
\text { September } 1990 \text { to August } 1999 .\end{array}$ & $\begin{array}{l}\text { Observation years } 1990 \text { to } 2001 \text { with } \\
\text { income data for January } 1989 \text { to } \\
\text { December } 2000\end{array}$ \\
\hline $\begin{array}{l}\text { Sample for } \\
\text { this paper }\end{array}$ & $\begin{array}{l}6,885 \text { people aged } 60 \text { or more } \\
\text { years and not in work in the } \\
\text { baseline year. }\end{array}$ & $\begin{array}{l}10,379 \text { people aged } 60 \text { or more years } \\
\text { and not in work in the baseline year. }\end{array}$ \\
\hline
\end{tabular}




\section{The definition and measurement of income mobility}

The understanding and measurement of income mobility was facilitated by distinguishing between relative and absolute mobility (see Shorrocks 1993; Jarvis and Jenkins 1995; Fields and Ok 1996, 1999). Relative mobility tracks changes in the relative ranking of individuals in the population, irrespective of absolute changes in their own income. By contrast, absolute mobility refers to changes in individuals' own incomes, irrespective of the effect of these changes on a person's rank position in the reference population. Thus, for instance, older people may experience upward mobility in an absolute sense (i.e. significantly higher income) even when they experience downward mobility relative to the overall population (as would occur if the income of the young adult population rises faster than the income of the older population).

We have taken the view that for income mobility over short periods, individuals are more likely to assign weight to absolute changes in their own incomes than to changes in their relative ranking, mainly because it is difficult to appreciate how one's relative position in the society has changed over a short period. Absolute income mobility measures a 'real income trajectory' that is directly relevant to the personal welfare of older people and a valid proxy for welfare gains or losses, whereas a measure of relative mobility is an abstract indicator of change in the rank position of the individual's income. Several different empirical measures of income mobility have been deployed. For the multivariate analyses, the concern was to measure the propensity for and correlates of changes in individuals' own incomes, thus an absolute mobility measure was used. The method was to create a single measure from all successive four consecutive year intervals, the percentage change in income over a single four-year interval:

$$
Y_{m o b}=\frac{Y_{t+3}-Y_{t}}{Y_{t}} \times 100
$$

where $Y_{t}$ and $Y_{t+3}$ is the first and the fourth year incomes respectively in a fouryear window at anytime during the study period.

Any sampled individual who was present throughout the nine-year study period (in the case of BHPS) will have six observations on income mobility. For the German SOEP sample members, there was a maximum of 12 annual waves of data and they yielded nine four-years intervals.

This approach to the measurement of income mobility partly solved a particular methodological problem: how to capture the effect of widowhood. Since this event can happen at any time, the annual income will include the components 
received before and after the event, making it difficult to measure the effect of widowhood on income mobility. The four-year unit of analysis to some extent removes this problem.

The explanatory or independent variables on demographic and labour market attributes and living arrangements, as well as income, time-period and sample attributes were also derived from changes over four-year intervals. Dummy variables represent each time-period to control for common trends and structural breaks. In addition, biographical variables were created from both the British and German surveys, to test the extent to which unemployment during earlier working life affected income events during old age. It should also be noted that the current study is an advance on that by Zaidi, Frick and Buechel (2003) that focussed exclusively on downward income mobility. This paper also captures the effect of additional explanatory variables, e.g. working life history variables were not explored in the earlier paper.

\section{Results}

\section{The income status of older people in Britain and Germany}

We first report the relative economic status of the older population in both countries. Table 2 compares the average (equivalent) income for older people and the non-elderly population (including children) at two points in time. In both countries, older people had a lower average income than the non-elderly, but the relative economic position of older people was worse in Britain than in Germany. This is partly attributable to the lower value of the British basic state pension relative to average earnings: it is linked to price inflation, and therefore has been losing its real value in relation to earnings. Moreover, as discussed above, the German public pensions have more generous earnings replacement rates, ${ }^{8}$ and the indexing of German public pensions has been closer to earnings growth than for either the basic state pension or private occupational pensions in Britain.

In both countries, elderly people were more likely to be poor than younger people, and the differences were larger in 1990/91 than in 1997/98. In both benchmark years, not surprisingly, the poverty differentials between older people and the non-elderly were more pronounced in Britain than in Germany. The prevalence of poverty among both older people and the non-elderly was

$8 \quad$ We refer to Börsch-Supan and Schnabel (1999) and Blundell and Johnson (1999) for comparable figures on replacement ratios in the two countries. The analyses presented in Schmähl (2003) and Emmerson (2003) corroborate this evidence. 
considerably higher in Britain than in Germany, particularly in 1990/91. ${ }^{9}$ One notable result is that the prevalence of poverty amongst older people declined sharply in Britain (from 41.6 to 29.8 per cent), whereas the corresponding temporal decline in Germany was comparatively moderate (from 20.3 to 19.9 per cent). The marked decline in Britain can largely be explained by the fact that the later (younger) cohorts were not only more likely to have had occupational pensions, but also to have received higher amounts from them (Johnson and Stears 1995). Consistent with this phenomenon, the results show that, as measured by the Gini coefficient, income inequality has increased amongst older people in Britain (as also among the non-elderly). In contrast, we observe no change in income inequality of the older population in Germany during the 1990s, but among the non-elderly income inequality increased. These results on overall trends in poverty and inequality set the context for the more detailed results which follow.

Table 2: Relative well-being of older people in Britain and Germany

\begin{tabular}{|c|c|c|c|c|c|c|}
\hline & \multicolumn{2}{|c|}{ Older people } & \multicolumn{2}{|c|}{ Not-elderly } & \multicolumn{2}{|c|}{$\begin{array}{c}\text { Elderly/non-elderly } \\
\text { ratio }\end{array}$} \\
\hline & Britain & Germany & Britain & Germany & Britain & Germany \\
\hline \multicolumn{7}{|c|}{ Median income $^{1}$} \\
\hline 1990/91 & 6,178 & 25,946 & 9,822 & 31,908 & 0.63 & 0.81 \\
\hline $1997 / 98$ & 7,013 & 27,735 & 10,218 & 32,240 & 0.69 & 0.86 \\
\hline \multicolumn{7}{|c|}{ Poverty rate ${ }^{2}$} \\
\hline 1990/91 & 41.6 & 20.3 & 18.3 & 10.6 & 2.27 & 1.92 \\
\hline $1997 / 98$ & 29.8 & 19.9 & 18.0 & 13.3 & 1.65 & 1.50 \\
\hline \multicolumn{7}{|c|}{ Income inequality (Gini coefficient) } \\
\hline 1990/91 & 0.275 & 0.251 & 0.302 & 0.258 & 0.91 & 0.97 \\
\hline $1997 / 98$ & 0.294 & 0.250 & 0.324 & 0.274 & 0.91 & 0.91 \\
\hline
\end{tabular}

Source: Authors' calculations from BHPS and SOEP.

Notes: Income is expressed in real terms in national currencies (pounds sterling and Deutschmarks). Britain refers to Great Britain and Germany refers to the territory of the former West Germany.

1. Equivalent household income, calculated using square-root-of-household-size as the equivalent scales.

2. The poverty line is 60 per cent of the median equivalent income.

9 This result is in line with the findings of Förster and Pellizzari (2000) and Smeeding (2001). 


\section{Income mobility in old age: descriptive results}

Transition matrices provide the most intuitive way to summarise income mobility. They report the probabilities of having moved from one income class to another (or to have remained in the same class) during an observation period. They have the additional virtue of being little affected by errors in the measurement of income, because income classes rather than individual incomes are employed. ${ }^{10}$

Table 3 presents the transitions in 'absolute' older people's incomes from the base year. It shows, firstly, that compared with their British counterparts, higher proportions of German older people remained in the same income group in year $t+3$ as in year $t$. For example, 73.1 per cent and 57.5 per cent of Germans in respectively the lowest and the next lowest income groups remained in these groups, whereas the corresponding numbers for Britain were 57.1 per cent and 43.8 per cent. In contrast, those who began in the two highest income groups showed very similar transitions in both countries. This can be interpreted as indicating greater overall (upward) mobility amongst low-income pensioners in Britain, or alternatively greater income rigidity amongst low-income groups in Germany. The British elderly in the second lowest income group are more likely to observe downward income mobility than their German counterparts. The matrices also show that in both countries there were significant differences by income quintile in the degree of income mobility experienced by the older population. Close to one-third of those in the bottom and top quintiles changed their income position, compared to approximately one-half in the three intermediate quintiles. In part, this can be explained by 'censorship', with those at the top and bottom end of the income distribution having restricted opportunities for change.

10 Cowell and Schluter (1998) refer to a distinction between single-stage and two-stage indices. Transition matrices are two-stage indices since they first allocate individuals into income classes and then examine mobility across the classes. They also point to the advantage of the two-stage index as being less sensitive to measurement errors. 
Table 3: Transition matrices of older people's income mobility in Britain and Germany

\begin{tabular}{cccccc}
\hline \hline $\begin{array}{c}\text { Income class } \\
\text { in base year } \\
\left(\mathbf{Y}_{\boldsymbol{t}}\right)\end{array}$ & \multicolumn{5}{c}{ Income class at end of four years $\left(\mathbf{Y}_{\boldsymbol{t}+3}\right)$} \\
\cline { 2 - 6 } I & \multicolumn{5}{c}{ Row percentages } \\
Britain & & & IV & V \\
I & 57.1 & 20.4 & 14.5 & 6.3 & 1.7 \\
II & 21.4 & 43.8 & 22.3 & 8.7 & 3.9 \\
III & 8.2 & 18.0 & 48.3 & 20.9 & 4.6 \\
IV & 3.8 & 5.9 & 18.7 & 52.4 & 19.2 \\
V & 2.0 & 2.5 & 4.3 & 16.9 & 74.4 \\
Germany & & & & & \\
I & 73.1 & 16.7 & 6.3 & 2.8 & 1.2 \\
II & 14.7 & 57.5 & 19.7 & 5.6 & 2.5 \\
III & 5.3 & 16.1 & 54.5 & 19.4 & 4.7 \\
IV & 2.8 & 7.0 & 19.2 & 51.8 & 19.3 \\
V & 1.8 & 2.8 & 5.0 & 18.5 & 71.9 \\
& & & & & \\
\hline \hline
\end{tabular}

Source: Authors' calculations from BHPS and SOEP.

Notes: Income classes I, II, III, IV and V refer respectively to the lowest to highest income quintiles. They are defined on the basis of the net equivalent household income for the older population in the base year $\left(\mathrm{Y}_{t}\right)$. The data refer to all available four-year periods during the 1990s.

\section{Aggregate indices of mobility}

Table 4 presents estimates of aggregate income mobility amongst older people using the Shorrocks (1993) measure and the Fields and Ok (1996) percentage measure. As discussed in detail in Zaidi et al. (2001), the Shorrocks index exploits the fact that inequality using income information for m-periods can never exceed a weighted sum of the individual period values. The weights used, $\mathrm{wk}$, are defined as mean income of each $\mathrm{k}$ period as a proportion of mean income for m-periods $\left(w_{k}=\mu^{k} / \mu\right)$. The index is formally written as:

$$
R(m)=1-\frac{I\left[\sum_{k}\left(Y_{k}\right)\right]}{\sum_{k} w_{k} I\left(Y_{k}\right)}
$$

where $I\left[\sum_{k}\left(Y_{k}\right)\right]$ refers to the inequality of total income for m-period (can also be referred to as 'permanent' inequality), and $I\left(Y_{k}\right)$ the inequality for period $\mathrm{k}$. 
$\mathrm{R}(\mathrm{m})$ is 1 in the case in which extending the accounting period of income to more than one wave removes all longer period inequality and therefore presents the case of perfect mobility. On the other hand, the index takes the value 0 when the longer-term inequality equals the weighted sum of the inequality in individual years, and this represents the case of complete immobility in (relative) incomes. ${ }^{11}$

Table 4: Aggregate indices of income mobility

\begin{tabular}{lcc}
\hline \hline & Britain & Germany \\
\hline Shorrocks (1978) mobility index: & & \\
Using Theil (GE (1)) & 0.139 & 0.091 \\
Using MLD (GE (0)) & 0.148 & 0.102 \\
Using Atkinson - 0.25 & 0.137 & 0.092 \\
Using Atkinson - 1.50 & 0.177 & 0.105 \\
Using Atkinson - 2.50 & 0.522 & 0.134 \\
& & \\
Fields and Ok (1996) measure: & & \\
'Percentage' income mobility & $23.6 \%$ & $17.6 \%$ \\
\hline \hline
\end{tabular}

Source: Authors' calculations from BHPS and SOEP. See text for an explanation of Shorrocks and Fields and Ok measures.

For Britain, the first estimate of Shorrocks measure for the older population is 0.14 (using the Theil measure of income inequality; see Cowell (2000) for an understanding of different measures of income inequality). This result shows that the inequality amongst the older population based on income from all four years is about 14 per cent smaller than the inequality in a single year, which represents a clear case of existence of income mobility amongst the older population. For Germany, the corresponding measure is clearly lower ( 9 per cent). Different inequality indices respond differently to changes in different parts of the distribution, it is therefore essential that the sensitivity of Shorrocks measure be tested for different measures of inequality indices. It is obvious from the results presented in Table 4 that for all inequality measures used, the income mobility as given by Shorrocks measure is greater for Britain than for Germany.

11 See Jarvis and Jenkins (1998) and Zaidi, Rake and Falkingham (2001) for a more detailed exposition of this index; and Atkinson, Bourguignon and Morrisson (1992: 268) for an evaluation of the index's conceptual basis. 
Note that Shorrocks measure is affected by the differential rates of income changes among individuals, and thus is in line with a relative income mobility measure. The index proposed by Fields and Ok (1996), on the other hand, reports on the total absolute change in income from year $t$ to year $t+3$ as a proportion of income in year $t$. This measure is specified as:

$$
m(x, y)=\frac{\sum_{i=1}^{N}\left|x_{i}-y_{i}\right|}{\sum_{i=1}^{N} x_{i}}
$$

where $\mathrm{N}$ is the number of individuals in the population, $x_{i}$ is the income in the origin year of individual $i$ and $y_{i}$ is the destination year income of the same individual. The estimated values of this index are also in line with the evidence from the absolute transition matrix and from Shorrocks measure: whatever the income mobility measure, British older people have been shown to have experienced greater income mobility than their German counterparts.

\section{The five-category income mobility outcome variable}

Income mobility outcomes can also be quantified on the basis of different thresholds of income changes and whether income is rising or falling (and the concept applied is the same as in the index developed by Fields and Ok). The outcome variable that we have used in Table 5 also used the four-year period and has five categories that indicate whether an individual has experienced:

1. Long-term downward income mobility (a fall in income by more than $15 \%$ ),

2. Short-term downward income mobility (a fall in income by $5-15 \%$ ),

3. No income mobility (change in income less than 5\%),

4. Short-term upward income mobility (a rise in income by $5-15 \%$ )

5. Long-term upward income mobility (a rise in income by more than $15 \%$ )

The immediate finding of the variable is that there was considerable income mobility amongst older people, and that it was significantly higher in Britain than in Germany. In particular, the percentage that experienced income immobility was clearly higher in Germany (31.6\%) than in Britain (24.5\%). The country differential applied to both upward and downward income mobility, and was particularly marked for long-term upward income mobility. One explanation of a high rate of upward income mobility among British older people is that they are entitled to additional age-related health and disabilityrelated cash benefits. Variations in the take-up of means-tested benefits also produced more upward income mobility for British older people. 
Table 5: Absolute income mobility as a five outcome categorical variable

\begin{tabular}{|c|c|c|}
\hline \multirow[b]{2}{*}{ Five-category measure of income mobility } & \multicolumn{2}{|c|}{$\begin{array}{c}\text { Income mobility between } \\
\text { year } t \text { and year }(t+3)\end{array}$} \\
\hline & Britain & Germany \\
\hline & \multicolumn{2}{|c|}{ Column Percentages } \\
\hline $\begin{array}{l}\text { 1. Long-range downward income mobility } \\
(>15 \% \text { fall in income) }\end{array}$ & 20.8 & 17.1 \\
\hline $\begin{array}{l}\text { 2. Short-range downward income mobility } \\
(5-15 \% \text { fall in income })\end{array}$ & 12.4 & 15.5 \\
\hline $\begin{array}{l}\text { 3. No income mobility } \\
\text { (less than } 5 \% \text { change) }\end{array}$ & 24.5 & 31.6 \\
\hline $\begin{array}{l}\text { 4. Short-range upward income mobility } \\
(5-15 \% \text { rise in income })\end{array}$ & 14.4 & 15.1 \\
\hline $\begin{array}{l}\text { 5. Long-range upward income mobility } \\
(>15 \% \text { rise in income })\end{array}$ & 28.0 & 20.8 \\
\hline Total & 100.0 & 100.0 \\
\hline
\end{tabular}

Source: Authors' calculations from BHPS and SOEP

\section{Income mobility in old age: regression results}

The dependent variable in the regression analyses is the percentage change in income over the four-year period (measured as a change between $\mathrm{t} 1$ and $\mathrm{t} 4$ ). Because data were pooled over several years of observation, we specified random-effects models that allow for the non-independence of individual observations across time.

\section{Composition of the total elderly population}

The descriptive statistics used as variables in the regression analysis are presented in Table 6. These show that the BHPS sample of older people had greater proportions aged 70 or more years, female and with a low level of education. These characteristics may be related to the higher rate of residence in residential care in Germany (who are excluded from the datasets), but this differential may alternatively be explained by greater attrition from the German sample. Other notable differences between the two samples are that more of the British older people were homeowners and thus enjoyed a substantial capital asset to buffer income shocks. More of the German sample, on the other hand, benefited from a high share of income from earnings-related pensions and higher pension income. A greater proportion of the German sample also reported ill-health and deteriorated health during the previous year. 
Table 6: Values of the explanatory and dependent variables by gender and country

\begin{tabular}{|c|c|c|c|c|c|c|}
\hline & \multicolumn{2}{|c|}{ All } & \multicolumn{2}{|c|}{ Males } & \multicolumn{2}{|c|}{ Females } \\
\hline & Britain & Germany & Britain & Germany & Britain & Germany \\
\hline Female & 0.64 & 0.61 & - & - & 1.00 & 1.00 \\
\hline Low education & 0.60 & 0.39 & 0.52 & 0.17 & 0.64 & 0.53 \\
\hline High education & 0.03 & 0.06 & 0.04 & 0.10 & 0.02 & 0.04 \\
\hline Age group 65-69 years & 0.28 & 0.30 & 0.31 & 0.32 & 0.27 & 0.29 \\
\hline Age group 70-79 years & 0.42 & 0.31 & 0.44 & 0.28 & 0.41 & 0.33 \\
\hline Age group 80-99 years & 0.14 & 0.09 & 0.13 & 0.08 & 0.14 & 0.10 \\
\hline Immigrant & 0.03 & 0.14 & 0.03 & 0.17 & 0.03 & 0.11 \\
\hline Became widower & 0.01 & 0.01 & 0.04 & 0.02 & - & - \\
\hline Became widow & 0.03 & 0.03 & - & - & 0.05 & 0.05 \\
\hline Became dependent & 0.01 & 0.01 & 0.00 & 0.01 & 0.01 & 0.00 \\
\hline Became independent & 0.02 & 0.04 & 0.02 & 0.05 & 0.02 & 0.04 \\
\hline $\begin{array}{l}\text { Lost employment } \\
\text { (current) }\end{array}$ & 0.04 & 0.10 & 0.05 & 0.12 & 0.03 & 0.09 \\
\hline $\begin{array}{l}\text { Had unemployment }(\leq 2 \\
\text { years })\end{array}$ & 0.14 & 0.15 & 0.19 & 0.21 & 0.11 & 0.10 \\
\hline $\begin{array}{l}\text { Had unemployment }(>2 \\
\text { years) }\end{array}$ & 0.08 & 0.10 & 0.09 & 0.12 & 0.07 & 0.09 \\
\hline Health status $=$ ill & 0.13 & 0.18 & 0.11 & 0.17 & 0.14 & 0.19 \\
\hline Health deteriorated & 0.05 & 0.25 & 0.05 & 0.25 & 0.05 & 0.26 \\
\hline Lowest income quintile & 0.20 & 0.18 & 0.13 & 0.13 & 0.23 & 0.20 \\
\hline 2nd income quintile & 0.20 & 0.18 & 0.18 & 0.16 & 0.22 & 0.19 \\
\hline 4th income quintile & 0.20 & 0.22 & 0.23 & 0.24 & 0.18 & 0.20 \\
\hline Highest income quintile & 0.20 & 0.22 & 0.24 & 0.25 & 0.18 & 0.20 \\
\hline Home owner & 0.65 & 0.51 & 0.70 & 0.55 & 0.62 & 0.48 \\
\hline Income share from ERP ${ }^{1}$ & 0.62 & 0.77 & 0.68 & 0.75 & 0.59 & 0.78 \\
\hline Survivor $^{2}$ & 0.64 & 0.45 & 0.64 & 0.39 & 0.64 & 0.48 \\
\hline \multicolumn{7}{|l|}{ Dependent variable } \\
\hline $\begin{array}{l}\text { Percentage change in } \\
\text { income }\end{array}$ & 8.91 & 4.27 & 8.52 & 3.63 & 9.14 & 4.69 \\
\hline Number of observations & 6,885 & 10,379 & 2,491 & 4,085 & 4,394 & 6,294 \\
\hline Number of groups & 1,618 & 1,985 & 579 & 837 & 1,039 & 1,148 \\
\hline
\end{tabular}

Source: Authors' calculations from BHPS and SOEP

Notes: 1. ERP: earnings-related pensions. 2. These individuals are present in the panel during the whole period (1991 to 1999 for Britain and 1991 to 2001 for Germany). 
Most of the between-country patterns held true for men and for women. One notable difference between the countries was with the gender differential in the prevalence of low educational status. In the British samples, 51.9 per cent of the men and 63.9 per cent of the women were in the low attainment group, while in the German samples the corresponding figures were 16.8 and 52.9. The disparity is consistent with the strong normative assumption or paradigm of 'male breadwinners' in Germany's conservative welfare regime: older men in Germany certainly received education to a higher level than either German women or British older men. With respect to the share of income from earningsrelated pensions, in Britain women had less than men (58.7 versus $67.5 \%$ ), but the opposite was the case in Germany ( 78.1 versus $75.2 \%$ ). Note that the high contribution of earnings-related pensions to the incomes of German women was in large part a result of widows' survivor benefits.

\section{Regression results for the overall sample}

The regression results for the overall sample are broadly similar for the two countries, at least in terms of the sign and statistical significance of the coefficients. In most instances, the coefficients were larger in Britain than in Germany. This report begins with the similarities in the results for the two countries, and then analyses the most important differences. The account features the attributes (e.g. education status) and changes in attributes (i.e. events, such as being widowed) that were linked with upward and downward income mobility.

In both countries, the likelihood of upward income mobility in old age was positively associated with three attributes: high educational status, homeownership and low income in the base year; and one event, a change to a more dependent living arrangement, i.e. having moved to live with someone other than a spouse or partner. ${ }^{12}$ The association with this particular change in living arrangements indicates it improved the incomes of the older people concerned, although the change may have been a defensive reaction to an income loss, i.e. widowhood results in a decline in income for many women. The change in living arrangement may be motivated by income as well as psychological and

12 A positive coefficient for those in the lowest quintiles and negative coefficients for those in the highest quintiles suggest a 'regression towards the mean' effect (see Bliss 1999 for various different interpretations of this phenomenon). In our view, underlying this result is measurement error in the reported income. While we acknowledged its significance to the results on income mobility, a full examination of the ways in which measurement errors in income affect indexes of income mobility is beyond the scope of this paper (for further discussion see Cowell and Schluter 1998). 
instrumental support considerations. ${ }^{13}$ The attributes 'low education status' and 'high income status in the base year' positively associated with downward income mobility, and also correlated with the event of widowhood for women, with a change in living arrangements towards independence, and with the end of employment. For the coefficients that had the same sign and significance in both countries, the magnitude was generally higher in Britain, and particularly so for income in the base year.

Turning to the marked differences in the results for the two countries, for men, becoming a widower produced a positive and significant coefficient only in Germany (+12.4), implying that the same event had an opposite effects in the two countries. Taking into account that in both countries becoming widowed associated with reduced income for women, the results underline the fact that, in Germany, most men are entitled to pension benefits in their own right - their income is less likely to be negatively affected by the event than is German women's. It should also be noted that this effect may be an artefact of the assumed economies of scale in living costs in shared households when equivalising income.

The significance of income composition on income mobility was analysed using the share of total income from an earnings-related pension. In Britain, a high share raised the likelihood of positive income mobility, but in Germany the coefficient was not statistically significant for both sexes although it was for men alone - an association to which we will shortly return. Moreover, a period of unemployment during working life was significant only for the German sample: those who had two or more years of being out-of-work were more likely to experience downward income mobility in old age. Two other notable differences were that, in Britain, women were more likely to have experienced downward income mobility than men, and in Germany, immigrants and those whose health had recently deteriorated were more likely to observe downward income mobility than others. The differential for the health variables may have been because of the availability in Britain of poor health (incapacity) social security benefits.

13 The interaction effect of becoming dependent and widowhood (with a lag) was not statistically significant, but there were only a few cases in this subgroup. 


\section{Table 7: Covariates of income mobility for the total population of elderly, by gender}

(Dependent variable: Percentage change in equivalised income (Random effects model)

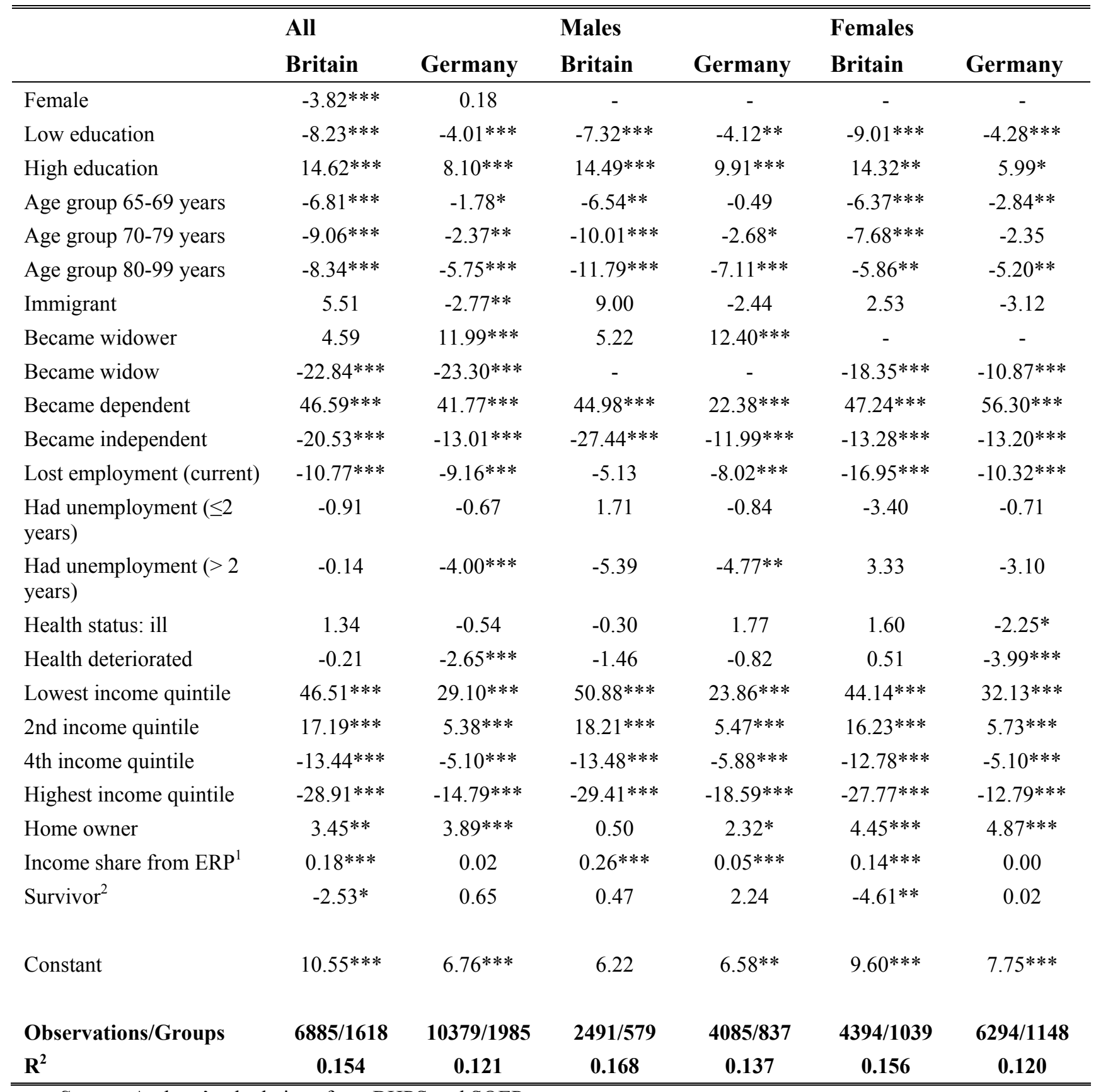

Source: Authors' calculations from BHPS and SOEP

Notes: The dependent variable is computed as the income change (in percentage) between the base year and three years later. Dummy variables controlling for the years of observation are also included, but not reported here. The reference group for educational attainment is 'medium' level of education; the youngest age group 6064 forms the reference group for age categories; A respondent is independent if (s)he lives alone or with partner only; Past unemployment experience refer to the unemployment experience during the whole of working life; Middle quintile forms the reference group for income quintiles.

1. ERP: earnings-related pensions.

2. These individuals are present in the panel during the whole period (1991 to 1999 for Britain and 1991 to 2001 for Germany).

Significance levels: $* * * \mathrm{p}<0.01, * * \mathrm{p}<0.05, * \mathrm{p}<0.10$; 


\section{Gender-specific results}

Examining first the results for the male sub-samples, becoming widowed was associated with upward income mobility, as in the overall sample, but the coefficient was statistically significant only for Germany, again reflecting the country's 'male breadwinner' model of pensions entitlements and the reduced entitlements of widowed wives. Changes in living arrangements strongly correlated with income mobility, as in the both-sex sample, but the coefficient was considerably higher in Britain than in Germany. Other male-specific results were that a high share of income from earnings-related pensions raised the likelihood of upward income mobility in both countries, and that health status and health deterioration had no significant effect on income mobility. Most other results were in line with the results for the aggregate (both sex) sample.

Turning to the results for the female sub-samples, there were notable differences with the male results. Women who moved to shared or more dependent living arrangements were more likely to experience upward income mobility in Germany than in Britain - although again the risk of endogeneity bias must be considered, since changes in living arrangements may be a consequence of income loss. The coefficients associated with a change to a more independent living arrangement were similar in the two countries only among women (-13.2), while for men the coefficient was higher in Britain (-27.4) than in Germany (-12.0). This may be because the different financial circumstances of men and women in the two countries induce the change in living arrangements. The effects of health status and of the share of income from an earnings-related pension were the same for women as in the overall sample (and thus different from those for men). For females, experience of unemployment during working life has no affect on income mobility in both countries.

\section{The results for low-income older people}

Separate analyses were conducted for the subgroup with less than median income in the base year. The results throw light on the particular factors that affect the income position of less well-off older people (Table 8). For instance, they show that the income position of men who became widowed improved not only in Germany but also among low-income British men. Moreover, a high level of education no longer associated with rising income, which may be because there were too few in the low-income category. A significant negative coefficient for those with low education and low income indicated that their income mobility experience was less likely to be upward than in the reference group, i.e. people with medium education. Another interesting result was that a high share of income from an earnings-related pension improved the income situation for British as well as German older low-income people. It can be expected that few low-income older people have a very diverse income 
portfolio and, therefore, that they are less likely than others to experience income mobility.

Table 8: Covariates of income mobility for the subgroup below the median Dependent variable: Percentage change in equivalised income (Random effects model)

\begin{tabular}{|c|c|c|c|c|c|c|}
\hline & \multicolumn{2}{|l|}{ All } & \multicolumn{2}{|l|}{ Males } & \multicolumn{2}{|l|}{ Females } \\
\hline & Britain & Germany & Britain & Germany & Britain & Germany \\
\hline Female & $-4.82 *$ & 2.21 & - & - & - & - \\
\hline Low education & $-7.73^{* * *}$ & $-8.78 * * *$ & -4.01 & $-5.25^{*}$ & $-10.92 * * *$ & $-10.16^{* * *}$ \\
\hline High education & -15.91 & -2.58 & -7.00 & -3.39 & -16.49 & -1.38 \\
\hline Age group 65-69 & $-7.88 * * *$ & -1.88 & -6.07 & -0.14 & $-6.66^{* *}$ & -2.79 \\
\hline Age group 70-79 & $-13.76^{* * *}$ & -1.89 & $-15.71 * * *$ & -3.81 & $-10.27 * * *$ & -0.96 \\
\hline Age group 80-99 & $-10.03^{* * *}$ & $-7.08 * *$ & $-13.72 * *$ & $-10.11^{* *}$ & -5.93 & -6.40 \\
\hline Immigrant & 11.48 & -4.63 & 16.95 & -5.20 & 9.65 & -5.50 \\
\hline Became widower & $17.34^{* *}$ & $10.98^{*}$ & $17.93^{* *}$ & $12.28 * *$ & - & - \\
\hline Became widow & $-33.27 * * *$ & $-19.36^{* * *}$ & - & - & $-16.09^{* * *}$ & $-7.91^{*}$ \\
\hline Became dependent & $55.50 * * *$ & $53.58 * * *$ & $50.82 * * *$ & $39.63 * * *$ & $55.88 * * *$ & $58.59^{* * *}$ \\
\hline Became independent & $-15.77^{*}$ & -2.04 & -15.96 & -3.03 & -12.95 & -1.19 \\
\hline $\begin{array}{l}\text { Lost employment } \\
\text { (current) }\end{array}$ & 4.65 & 1.36 & 9.76 & 1.66 & -4.88 & 1.01 \\
\hline $\begin{array}{l}\text { Had unemployment (up } \\
\text { to } 2 \text { years) }\end{array}$ & 2.10 & -3.18 & $8.95^{*}$ & -2.61 & -3.54 & -4.78 \\
\hline $\begin{array}{l}\text { Had unemployment ( }> \\
2 \text { years) }\end{array}$ & 3.22 & -3.87 & -5.18 & -4.73 & $10.17^{*}$ & -2.80 \\
\hline Health status $=$ ill & 1.96 & -1.49 & 2.75 & 2.83 & 1.22 & -3.45 \\
\hline Health deteriorated & 1.93 & $-5.45 * * *$ & 4.09 & -1.82 & 0.91 & $-7.34 * * *$ \\
\hline $\begin{array}{l}\text { Being in bottom } \\
\text { income quintile }\end{array}$ & $46.39 * * *$ & $38.11 * * *$ & $52.06 * * *$ & $26.99 * * *$ & $43.27 * * *$ & $43.06^{* * *}$ \\
\hline Being in 2nd quintile & $13.87 * * *$ & $8.28 * * *$ & $15.61 * * *$ & $5.94 * *$ & $12.79 * * *$ & $9.53 * * *$ \\
\hline Being in 4th quintile & - & - & - & - & - & - \\
\hline Being in top quintile & - & - & - & - & - & - \\
\hline Home owner & 0.36 & $4.18^{* *}$ & -4.87 & 0.36 & 2.28 & $6.51 * *$ \\
\hline $\begin{array}{l}\text { Share in earnings- } \\
\text { related pension }\end{array}$ & $0.23 * * *$ & $0.08 * *$ & $0.42 * * *$ & 0.05 & $0.14^{* * *}$ & $0.09 * *$ \\
\hline $\begin{array}{l}\text { Survivor (member } \\
\text { balanced panel) }\end{array}$ & 0.887 & -0.77 & 5.09 & 2.61 & -4.52 & -2.57 \\
\hline Constant & $9.75^{* *}$ & -2.26 & -1.20 & 3.50 & 10.96 & -2.47 \\
\hline Observations / Groups & $3437 / 1007$ & $4783 / 1188$ & $1020 / 328$ & $1609 / 445$ & $2417 / 679$ & $3174 / 743$ \\
\hline R2 & 0.119 & 0.069 & 0.186 & 0.068 & 0.108 & 0.076 \\
\hline
\end{tabular}

Source: Authors' calculations from BHPS and SOEP

Notes: See Table 7. 
When disaggregated by gender, unlike for the total population the coefficient for 'high education' was insignificant and, therefore, the attribute did not associate with upward income mobility. Another notable finding particular to the low-income sample was that a change in living arrangement towards independence produced insignificant coefficients in the two countries, and therefore no evidence that it associated with downward income mobility (contrast with Table 7). Furthermore, the end of employment did not correlate with downward income mobility.

\section{Conclusions and policy implications}

The empirical analyses reported in this paper provide strong evidence of associations between the different welfare and old age income regimes of Germany and Britain and the income risks that attach to various attributes and life-course transitions experienced by older people. The main finding is that oldage income mobility is more pronounced in Britain than in Germany. The regression results have shown that a relatively high probability of income mobility during the 1990s was associated particularly with widowhood for women, and changes in living arrangements and employment status. The strongest difference between the two countries was that only in Germany did unemployment for more than two years during working life have a significant and negative impact on late-life income changes. On the other hand, only in Britain did a high share of income from an earnings-related pension have a significant and positive effect on old-age income mobility.

One policy conclusion is that there is a need for further scrutiny of the social security safety net to safeguard against the hazard of income volatility in old age. Specifically, positive policy incentives to encourage flexible living arrangements for older people, in particular to encourage them to live with younger relatives will improve the income position of older people. A greater protection from unemployment during working life and its long-term impact on income in old age is required, particularly in Germany. A renunciation of the 'male breadwinner' model of social insurance in Germany would ameliorate the income risks faced by older women in that country. 


\section{References}

Atkinson, A.B., Bourguignon, F. and Morrisson, C. (1992), Empirical Studies Of Earnings Mobility. Harwood: Philadelphia.

Bliss, C. (1999), 'Galton's fallacy and economic convergence', Oxford Economic Papers, 51, 4-14.

Blundell, R. and Johnson, P. (1999), 'Pensions and retirement in the United Kingdom', in Gruber, J. and D.A. Wise (eds), Social Security and Retirement around the World. Chicago: University of Chicago Press.

Böheim, R. and Jenkins, S.P. (2000), Current Income versus Annual Income Measures: Do They Provide Different Pictures of Britain's Income Distribution? Report to the Department of Social Security, ISER Working Paper 2000-16, University of Essex, Colchester, Essex.

Börsch-Supan, A. and Schnabel, R. (1999), 'Social security and retirement in Germany', in Gruber, J. and D.A. Wise (eds), Social Security and Retirement around the World. Chicago: University of Chicago Press.

Börsch-Supan, A. (2001), Pension Reform In Six Countries: What Can We Learn From Each Other? Berlin: Springer.

Burkhauser, R. V., Butrica, B. A., Daly, M. C. \& Lillard, D. R. (2001), 'The Cross-National Equivalent File: A product of cross-national research', in I. Becker, N. Ott, \& G. Rolf (eds.), Soziale Sicherung in einer dynamischen Gesellschaft. Papers in Honour of the 65th Birthday of Richard Hauser. Campus: Frankfurt/New York.

Burkhauser, R.V., Lillard, D.R. and Valenti, P.M. (2001), 'How Exits from the Labour Force or Death Impact Household Income: A Four Country Comparison of Public and Private Income Support'. Paper presented at the BHPS-2001 conference, University of Essex, Colchester.

Cowell, F.A. (2000), 'Measurement of Inequality', in Atkinson, A.B and Bourguignon, F. (eds) Handbook of Income Distribution. Oxford: Elsevier.

Cowell, F.A. and Schluter, C. (1998), Measuring Income Mobility with Dirty Data. CASE Paper 16, Centre for Analysis of Social Exclusion, London School of Economics, London.

Dilnot, A., Disney, R., Johnson, P. and Whitehouse, E. (1994), Pensions Policy in the UK: An Economic Analysis. Institute of Fiscal Studies, London.

Disney, R. and Whitehouse, E. (2001), Cross-Country Comparisons of Pensioners' Incomes. Department of Social Security (DSS) Research Report 142, DSS, Leeds, West Yorkshire. 
Disney, R., Grundy, E. and Johnson, P. (1997), The Dynamics of Retirement. London: Stationery Office.

Emmerson, C. and Johnson, P. (2001), 'Pension provision in the United Kingdom', in Disney, R. and Johnson, P. (eds), Pension Systems and Retirement Incomes Across OECD Countries. Cheltenham, Gloucestershire: Edward Elgar.

Emmerson, C. (2003), 'Pension reform in the United Kingdom: increasing the role of private provision?', in Clark, G. and Whiteside, N. (eds), Pension Security in the 21st Century: Redrawing the Public-Private Debate. Oxford: Oxford University Press.

Fields, G.S. and Ok, E. A. (1999), 'Measuring movement of incomes', Economica, 66, 264, 455-71.

Fields, G.S. and Ok, E.A. (1996), 'The meaning and measurement of income mobility', Journal of Economic Theory, 71, 2, 349-77.

Förster, M.F. and Pellizzari, M. (2000), Trends and Driving Factors in Income Distribution and Poverty in the OECD Area. Labour Market and Social Policy Occasional Paper 42, Organisation for Economic Co-operation and Development, Paris.

Government Actuary's Department (2003), Occupational Pension Schemes 2000: Eleventh Survey. London: Government Actuary.

Hagenaars, A.J.M., De Vos, K. and Zaidi, A. (1994), Poverty Statistics in the Late 1980s: Research Based On Micro-Data. Official Publications of the European Communities, Luxembourg.

Holden, K.C., Burkhauser, R.V. and Feaster, D.J. (1988), 'The timing of falls into poverty after retirement and widowhood', Demography, 25, 3, 40514.

Holden, K.C., Burkhauser, R.V. and Feaster, D.J. (1986), 'Income transitions at older stages of life: the dynamics of poverty', The Gerontologist, 26, 3, 292-7.

Hurd, M. and Wise, D.A. (1989), 'The wealth and poverty of widows: assets before and after the husband's death', in Wise, D.A. (ed.), The Economics of Ageing. Chicago: University of Chicago Press.

Johnson, P. and Stears, G. (1995), 'Pension income inequality', Fiscal Studies, $16,4,69-93$.

Jarvis, S. and Jenkins, S.P. (1998), 'How much income mobility is there in Britain?', Economic Journal, 108, 447, 428-43. 
Jarvis, S. and Jenkins, S. (1995), Do the Poor Stay Poor? New Evidence about Income Dynamics from the British Household Panel Survey. Institute for Social and Economic Research, University of Essex, Colchester, Essex.

Schmähl, W. (1998), 'Recent developments of pension schemes in Germany: present and future tasks in conflict', Labour, 12, 1, 143-68.

Schmähl, W. (2003), 'Private pensions as partial substitute for public pensions in Germany', in Clark, G. and Whiteside, N. (eds), Pension Security in the 21st Century: Redrawing the Public-Private Debate. Oxford: Oxford University Press.

Shorrocks, A.F. (1993), 'On the Hart measure of income mobility', pp.3-21 in Casson, M. and Creedy, J. (eds), Industrial Concentration and Economic Inequality, Aldershot, Hampshire: Edward Elgar.

Shorrocks, A.F. (1978), 'Income inequality and income mobility', Journal of Economic Theory, 19, 376-93.

Smeeding, T.M. (2001), Income Maintenance in Old Age: What Can Be Learned from Cross-National Comparisons? Luxembourg Income Study Working Paper 263, Maxwell School of Citizenship and Public Affairs, Syracuse, New York.

Torrey, B. B. and Smeeding, T. M. (1992), 'Comparative economic status of the elderly in eight countries: policy lessons from the Luxembourg income study and the international database on aging', Research on Economic Inequality, 3, 81-113.

Tsakloglou, P. (1996), 'Elderly and non-elderly in the European Union: A comparison of living standards', Review of Income and Wealth, 3, 27191.

Zaidi, A., Rake, K. and Falkingham, J. (2001), Income Mobility in Later Life. SAGE Research Group Discussion Paper 3, London School of Economics, London.

Zaidi, A. and De Vos, K. (2002), Income mobility of the elderly in Great Britain and the Netherlands: A Comparative Investigation. SAGE Research Group Discussion Paper 9, London School of Economics, London.

Zaidi, A, Frick, J. and Buechel, F. (2003), 'Income risks within retirement in Great Britain and Germany', Journal of Applied Social Science Studies, 123, 1, 163-76. (Special issue.) 